
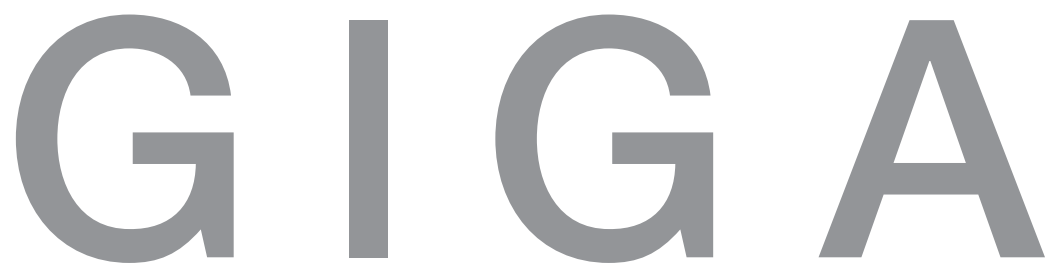

Working

German

Institute of Global and Area Studies Papers

Leibniz-Institut für Globale und Regionale Studien

GIGA Research Unit:

Institute of African Affairs

Political Discourse in Football Coverage The Cases of Côte d'Ivoire and Ghana

Andreas Mehler 


\section{GIGA Working Papers}

Edited by GIGA German Institute of Global and Area Studies / Leibniz-Institut für Globale und Regionale Studien.

The Working Paper Series serves to disseminate the research results of work in progress prior to publication to encourage the exchange of ideas and academic debate. An objective of the series is to get the findings out quickly, even if the presentations are less than fully polished. Inclusion of a paper in the Working Paper Series does not constitute publication and should not limit publication in any other venue. Copyright remains with the authors. When Working Papers are eventually accepted by or published in a journal or book, the correct citation reference and, if possible, the corresponding link will then be included in the Working Papers website at:

www.giga-hamburg.de/workingpapers.

GIGA research unit responsible for this issue: Research Unit: Institute of African Affairs.

Editor of the GIGA Working Paper Series: Bert Hoffmann <hoffmann@giga-hamburg.de> Copyright for this issue: (C) Andreas Mehler

Editorial assistant and production: Verena Kohler

All GIGA Working Papers are available online and free of charge at the website: www.giga-hamburg.de/workingpapers. Working Papers can also be ordered in print. For production and mailing a cover fee of $€ 5$ is charged. For orders or any requests please contact:

e-mail: workingpapers@giga-hamburg.de

phone: ++49 (0)40 - 42825548

GIGA German Institute of Global and Area Studies /

Leibniz-Institut für Globale und Regionale Studien

Neuer Jungfernstieg 21

20354 Hamburg

Germany

E-mail: info@giga-hamburg.de

Website: www.giga-hamburg.de 


\title{
Political Discourse in Football Coverage - The Cases of Côte d'Ivoire and Ghana
}

\begin{abstract}
Football coverage in newspapers is both an arena for and a mirror of political discourse within a society. The paper argues that discourses within football coverage referring to political issues reflect dominant - and, possibly, contesting - "truths", which themselves are linked to power relations and political struggles within a given society. The comparison of Côte d'Ivoire and Ghana, two neighbouring countries in very different conditions (particularly with regard to their historical trajectories and the degree of societal consensus), and more particularly, the comparison of dominant discourses on the topics of patriotism, peace and good governance related to the World Cup qualification of both national teams supports the hypothesis of a strong context-relatedness of a politically loaded "football language". For instance, whereas in Ghana patriotism is, when football comes in, quickly merged with pan-africanism, the Ivorian team renewed the heated political debate about "Ivorianess" by putting forward a notion of inclusive patriotism.
\end{abstract}

Key words: football, political discourse, Côte d'Ivoire, Ghana, patriotism, good governance, peace

\section{Dr. Andreas Mehler}

is political scientist and director of the GIGA Institute of African Affairs in Hamburg. Contact: mehler@giga-hamburg.de·Website: http://staff.giga-hamburg.de/mehler 


\section{Zusammenfassung}

\section{Politischer Diskurs in der Fußball-Berichterstattung -}

\section{Die Fälle Côte d'Ivoire und Ghana}

Die Fußball-Berichterstattung in Zeitungen stellt eine Arena, aber auch einen Spiegel der politischen Diskurse innerhalb von Gesellschaften dar. Der vorliegende Text argumentiert, dass Sportberichte dominante, aber auch Gegen-“Wahrheiten” reflektieren, die in Verbindung zu Herrschaftsbeziehungen und politischen Auseinandersetzungen in einer bestimmten Gesellschaft stehen. Der Vergleich von Côte d'Ivoire und Ghana, Nachbarstaaten in sehr unterschiedlichem aktuellen Kontext (im Hinblick auf den Verlauf der jüngeren Geschichte und in der Ausprägung von gesellschaftlichem Konsens), und im besonderen der Vergleich von prägenden Diskursen zu den Themen Patriotismus, Frieden und Good Governance in der Berichterstattung über Qualifikation zur sowie Leistung bei der Fußball-Weltmeisterschaft 2006 durch beide Nationalmannschaften stützt die Hypothese einer starken Kontextgebundenheit der politisch aufgeladenen „Fußballsprache“. Während in Ghana beispielsweise Patriotismus schnell mit „Panafrikanismus“ gepaart wird, sobald von Fußball die Rede ist, hat das ivorische Team die politisch hitzig geführte Debatte über die „Ivoirité“ weiterentwickelt, indem eine inklusivere Form des Patriotismus breite Unterstützung findet. 


\section{Article Outline}

1. Introduction

2. Patriotism

3. Peace

4. Governance

5. Patriotism: “The Need to Prove" Versus "Self-Esteem"

6. Peace: To Have or to Have Not

7. Good Governance: Learning from Football or Vice Versa

8. Conclusions

\section{Introduction}

With football coverage in newspapers drawing a large number and wide range of readers in many African countries - arguably more than political issues - it is both an arena for and a mirror of political discourse within a society. Knowledge, in football coverage, is produced and reproduced as political ideology.

Sports coverage can support a particular discourse on political and societal issues, which also as a result of concurring tendencies in other fields of social life - acquires a hegemonic position. Thus, it is argued that discourses within football coverage referring to political issues reflect dominant - and, possibly, contesting - "truths", which themselves are linked to power relations and political struggles within a given society. Objectivity is not sought in this endeavour. The media reports chosen may not even be "representative" of what "people" think. They just show the range of positions adopted. 
On this background, the paper analyses whether and in what way different political contexts influence style and content of football coverage and what implications this may have. Therefore, this contribution does not aim at proving again the direct nexus between sports and politics in Africa. ${ }^{1}$

The cases of neighbouring Côte d'Ivoire and Ghana are advanced as evidence. Both countries are frequently compared as they have much in common (distribution of climate zones, religious communities, culture, export products etc.), but followed quite different paths with regard to politics and economic development since independence. ${ }^{2}$. In these two cases, coverage of the national team's qualification for and performance at the world cup 2006 took place within highly different political contexts (violent conflict/identity crisis/disorder in Côte d'Ivoire - peace/self-esteem/consolidation of democracy in Ghana).

For this paper, for about a year electronically available newspapers and other internet sources were screened on their content regarding football and politics in both Ghana and Côte d'Ivoire. Just one more word on the empirical basis of this study. It is difficult to claim representativity when using text analysis as the main method. This is not the aim here. However, a broad sample of sources needs to be consulted when - in a more limited research design - the range of opinions should be exemplified. Between July 2005 and July 2006 about 30 internet sites and a number of other available sources from Ghana and Côte d'Ivoire were regularly consulted; about 100 telling examples were considered for inclusion in this paper. ${ }^{3}$ I admit that it was easier to get telling examples of the political use of football in the latter country. However, there is a degree of ambivalence as to who is using or abusing whom, as will be shown in some detail.

When selecting texts for quotation this paper tries to reflect a broad range of opinions. It should be clear from the outset that while the States' Presidents deliver their speeches the selection of quotes from these is the intellectual act of the Ghanaian and Ivorian journalists who write about them. It translates what they find important and what not and which message they want to convey. However, the author bears responsibility for selecting telling examples based on his prior understanding of matters. In sum, the quotes used were first for-

1 See for a recent and well documented article Poli/Dietschy 2006; for a more dated example Engel et al. 1994.

2 A classic example is Philip Foster; Aristide R. Zolberg (eds.): Ghana and The Ivory Coast. Perspectives on Modernization. Chicago and London: University of Chicago Press.

3 The following newspapers and websites were regularly checked: Côte d'Ivoire: Fraternité Matin, Notre Voie, Le Jour, DNA, Le Matin d'Abidjan, Le Patriote, Le Nouveau Réveil, L'Intelligent d'Abidjan, Le Courrier d'Abidjan, 24 heures, Nord-Sud Média, Le Front, L'Inter, Soir Info, www.abidjan.net, www.abidjanlumières.com; Ghana: Accra Daily mail, Accra Daily Graphic, Ghana Review International, Ghanaian Chronicle, Ghanaian Times, Ghana Palaver, Public Agenda, the Heritage; www.ghanaweb.com. I want to thank Eric Tchouamou Njoya, Katharina Puvogel and Ingo Haltermann for their support, particularly in finding some of those telling quotations. 
mulated by specific actors of the political game; second, selected, sometimes manipulated by journalists; and third, selected and commented by the author of this paper. It is a matter of transparency to lay this procedure open. As mentioned, the aim of this paper can not be to draw an "objective" picture of patriotism, peace, and good governance in Ghana and Côte d'Ivoire. Rather, the aim is to describe and analyse the social construction of realities.

This analysis focuses on three particular issues having a politically loaded meaning and their recurrent use in sports coverage, namely patriotism, peace and governance. It tries to summarise why these three topics are important, what they mean in both Côte d'Ivoire and Ghana and how they are translated into the soccer world.

\section{Patriotism}

This term has extraordinarily strong political connotations in Côte d'Ivoire. Both progovernment militias (jeunes patriotes) and rebels (Mouvement Patriotique de la Côte d'Ivoire) as well as the Northern-based opposition party RDR with its newspaper Le Patriote use the notion explicitly. The backlash of the dangerous xenophobic discourse on "Ivoirité" (Ivoirianness) - one main driving force behind the rebellion turned into a civil war in 2002 - concerns national identity. Ivoirité might be seen as an exaggeration of patriotism leading to the exclusion of "Them" groups (Coulibaly 1995, Dozon 2000, Losch 2000). As long as both sides claim to be patriots there is however rather a competition around the term. Who is the better patriot: the leaders Gbagbo, Ouattara, Bédié or Soro? The parties FPI, RDR, PDCI or the "Forces Nouvelles"4?

In Ghana Patriotism has an obvious historical dimension given that Ghana was the first country achieving independence in sub-Saharan Africa in 1957. Pan-africanist leanings of first President Kwame Nkrumah (Hadjor 1988: 88ff.) may be portrayed as a different strand of thought, putting Patriotism outside the narrow framework of the nation-state. Nkrumah wrote in his book "Revolutionary Path":

"We can not allow ourselves to be so disorganised and divided. [...]. We are Africans first and last, and as Africans our best interests can only be served by uniting within an African Community." (Nkrumah 1973: 223).

Nkrumah continues to inspire a new generation of Africans despite the demise of his more or less socialist, pan-africanist experiment in Ghana. Since the 1960s strong ideological ten-

4 FPI: Front Populaire Ivoirien (Gbagbo), RDR: Rassemblement des Républicains (Ouattara), PDCI: Parti Démocratique de la Côte d'Ivoire (Bédié); the three main political parties (for the second one only since the mid-1990s). The Forces Nouvelles is the umbrella body of the different rebel organisations under the leadership of Guillaume Soro. 
sions could be detected leading to the development of political families and traditions in which political parties and individual leaders would place themselves. ${ }^{5}$ President Kuffour's party today clearly claims the label of patriotism in its very name - "National Patriotic Party" - while the opposing parties may claim rather the left-leaning label of progress.

Football and particularly the World Cup that confronts national teams is of course - at a world-wide level - an opportunity to display, live, reinforce, and challenge patriotism. ${ }^{6}$

\section{Peace}

Evidently, peace is a more obvious topic in Côte d'Ivoire than in Ghana. Côte d'Ivoire, which for a long time seemed to be a safe haven in a troubled sub-region, is in an on-going and painful peace process after a rebellion in September 2002 that led to a division of the territory into a loyalist south and a rebel north (Akindes 2004, Glaser/Smith 2005, Mehler 2002, 2003, 2005, Smith 2003). The political elite is equally split and all camps accuse each other of war-mongering while claiming to stand themselves for peace.

Ghana has experienced a geographically limited violent conflict in the eastern part of its Northern Region. In early 1994, a full scale ethnic war broke out between the ethnic groups of the Konkomba and the Nanumba. Within the brief span of ten days, over 1,000 lives were lost and more than 150 villages were destroyed together with thousands of acre of farmland and millions of cedis worth of produce (Akwetey 1996). The region is still not completely pacified. In March 2002, the Ya Naa, the King of the Dagomba ethnic group, was beheaded and killed together with 29 clansmen in violent clashes (MacGaffey 2006). But Ghana has achieved a much more positive status during the last decade, namely as a main peaceprojecting state at least for West Africa - UN secretary general Kofi Annan (and the Kofi Annan Peacekeeping Training Centre in Ghana) helping.

Dialogue and peaceful competition is a main topic of international football propaganda. This is not always in conformity with reality. In November 1993 a match between both countries' top teams ASEC and Kotoko in Abidjan degenerated when Ivorian fans attacked supporters

5 Today's Convention People's Party (CPP, founded by Nkrumah) claims to be socialist in a Nkrumaist tradition, in this not very different from PNC (Peoples National Convention). From their point of view both more influential parties are respectively regarded as "conservative" (NPP) or "liberal" (NDC; National Democratic Congress). Those labels might not be accurate or could become more and more meaningless. Changes have taken place over time. Nugent (2004, 2001: 420) argues that Ghana is heading towards a two-party system with the NPP no longer an entirely urban/youth party and the NDC no longer a party representing the rural poor. However, allusions to the Nkrumah and the Busia/Danquah tradition remain numerous. See also Ghanaweb, 2006.

6 Boer (2004: 75) recalls that the African Nations Cups 2000 co-hosted by Ghana and Nigeria was an opportunity to display a "hyper-Nigerian nationalism". 
of the guest team causing more than 20 deaths. ${ }^{7}$ Today, foremost in Côte d'Ivoire, football is presented as a factor of unity and peace, not least supported by the actual behaviour of the national team - in fact the team has recurrently appealed to the politicians of the country to support the peace process. The mothers of the team, coming from diverse backgrounds, have created an association called AMEF (Amicale des mamans des Eléphants footballeurs), in itself another example of unity and peace. ${ }^{8}$

\section{Governance}

Until the 1990s, Ghana has experienced a recurrent change from autocratic civilian to military regimes. Its economy had also its ups and downs. Today, however, Ghana is portrayed internationally as one of the African model states regarding good governance, a bit too quickly probably. The country has undergone a peer-review in the framework of the African Peer Review Mechanism (APRM): Twenty-six countries including ten from West Africa, have currently notified the Implementation Committee of NEPAD Heads of States and Governments that they wished to participate in this peer review process that should attest progress made in several fields of governance. Ghana was selected to be the first country to be assessed within the APRM framework. ${ }^{10}$ The final Country Review Report attests Ghana remarkable progress in the issues of democratic participation and human rights. It also stresses the country's positive role in the implementation of peace towards the region. Nevertheless it also identifies some areas in which improvement remains badly needed. These include combating corruption, development effectiveness, poverty reduction and the fight against unemployment. ${ }^{11}$

7 See Ulf Engel; Peter Körner; Andreas Mehler (1995): “and it's a gooaal!” - Fußball in Afrika, in: Rolf Hofmeier (Hrsg.): Afrika Jahrbuch 1994, Hamburg, pp. 61-70, here p. 68.

8 For a strong case see Armstrong (2004: 196), with regard to Liberia: "There are instances in the 1990s wherein football could be said to have stopped armed conflict.".

9 See e.g. the Bertelsmann Transformation Index: "In Afrika widerlegen Mauritius, Botswana, Südafrika und Ghana durch gutes politisches Management die These vom „verlorenen Kontinent". (...) So konnten in Afrika vor allem Senegal, Ghana und Madagaskar durch Good Governance entscheidende Transformationserfolge erzielen." (BTI 2006).

10 The peer review mechanism examines good governance of countries in three aspects: effectiveness of utilities, accountability of parliament and an independence of the judiciary

11 NEPAD, 2005. Douada Touré, a UN resident coordinator recently commented: “Ghana has made a lot of progress in its democratic governance and respect for human rights. However there are some important governance aspects identified in the APRM report for which the effort towards improvement remains critical. These include reinforced transparency and accountability systems to achieve zero tolerance on corruption; decentralisation for development effectiveness and widening the resource base for financing the economy including attractive measures for even more workers remittances.", http://allafrica.com/stories/200606230102.html, access: June 23, 2006. 
Critical thoughts of a broader public (and opposition parties) concern the actual quality of government and governance. ${ }^{12}$ A survey of popular perceptions conducted by the Ghana Integrity Initiative in four cities in 2005 revealed that $60 \%$ perceived it as having worsened in recent years. ${ }^{13}$

Côte d'Ivoire has a long history of corruption at a high level of the state involving nonIvorian business circles. The democratisation process itself started late. After a formal opening towards a multi-party system in 1990 the room for manoeuvre of opposition parties was severely curtailed and elections were systematically manipulated during the reign of founding father Houtphouët-Boigny. In fact, democratisation only began in earnest after a coup d'Etat in late 1999. President Gbagbo was elected - according to some observers he was "badly elected" - in 2000"14. However, in comparison to elections in the 1990s (Coulibaly 1995) the outcome of these and the following municipal and legislative elections were not so far off the mark. In fact, important reforms were prepared by the FPI-dominated government before the rebellion started (Mehler 2002). With the outbreak of violence new and old forms of "informality" got the upper hand again with serious accusations of embezzlement, self-enrichment, illegal arms purchases etc.

There are a number of familiar governance indicators used by different organisations. A quick comparison of Ghana's and Côte d'Ivoire's rating of three indicators used by the World Bank may be enough to get an idea. ${ }^{15}$

12 Pointing e.g. to the so-called "Bambagate" or a decline in the Transparency International rating from rank 51 to 73 during 2004, see Paul Nugent: Ghana, in: Andreas Mehler et al. (eds.), Africa Yearbook 2004, Leiden: Brill 2005: 79.

13 Paul Nugent: Ghana, in: Andreas Mehler et al. (eds.): Africa Yearbook 2005, Leiden: Brill 2006 (forthcoming). Nugent continues "The allegation that Kufuor's administration was deeply nepotistic also resurfaced, forcing the president on to the defensive. On 18 May, the president addressed members of the armed forces and pleaded that only two of his ministers were family members."

14 E.g. Tiemoko Coulibaly: Lente décomposition en Côte-d'Ivoire, Le Monde Diplomatique, novembre 2002.

15 Source: Kaufmann D. et al. (2005): Governance Matters IV: Governance Indicators for 1996-2004. 
Figure: Comparison between 2004, 1998 (top-bottom order), country's percentile rank

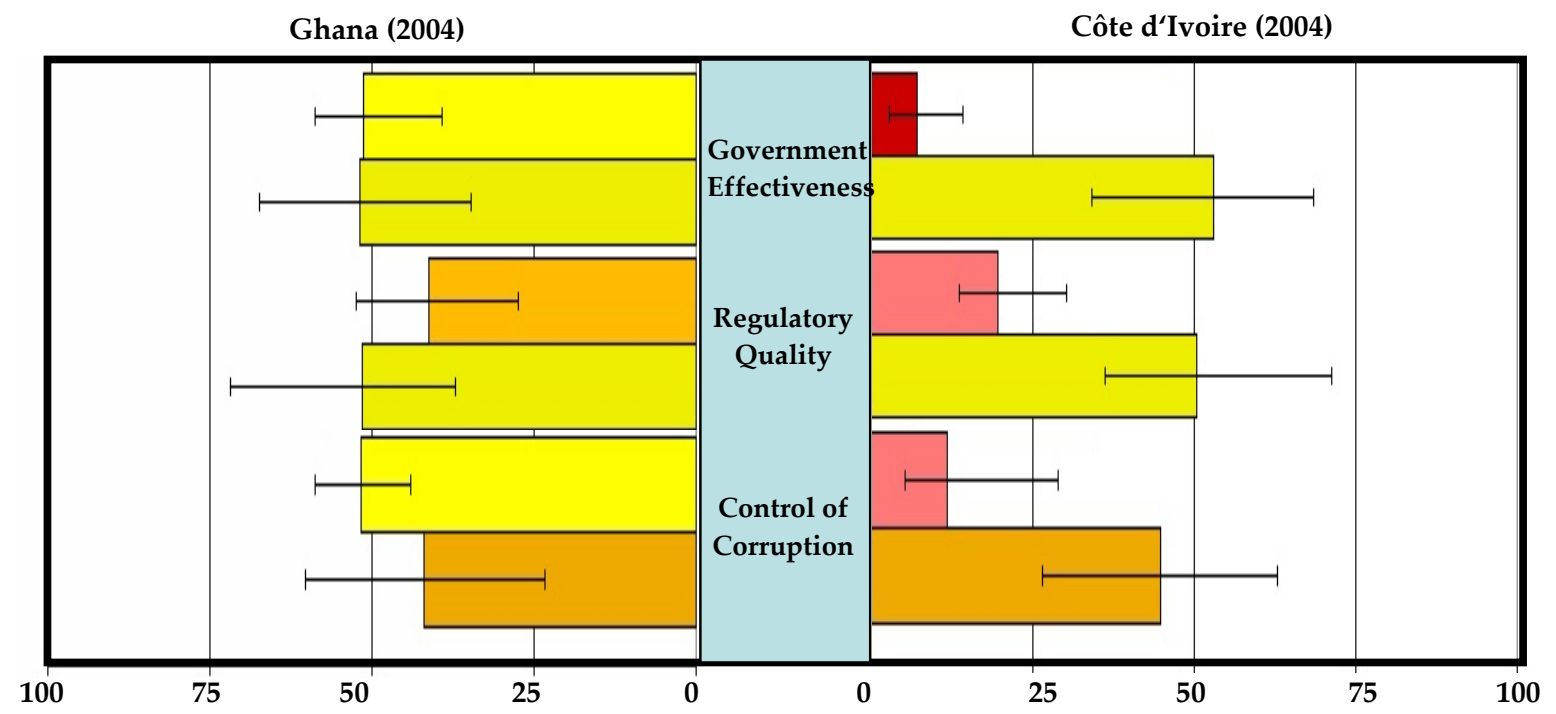

Governance is a main issue in football circles, not least because of recurrent management problems of the world body FIFA as well as those of national football federations. ${ }^{16}$ The national federations in Côte d'Ivoire and Ghana both have rather positive images of professionalism compared to other institutions in both countries.

\section{Patriotism: "The Need to Prove" Versus "Self-Esteem"}

In the case of Ivory Coast, the President's party (FPI) daily Notre Voie on 16 May of this year reported from an interesting event in the home village of the Ivorian football federation's President Jacques Anouma ${ }^{17}$ where both state President Gbagbo and Anouma were celebrated. I will quote from this article several times. Large parts of the article in Notre Voie are direct quotes from different speeches, but they translate a certain spirit. E.g. FPI Member of Parliament Mobio Joseph is quoted (with "Elephants" being the popular short-hand code for the Ivorian football team): "Pour lui, les Eléphants au mondial, c'est la Côte d'Ivoire qui

16 The latest example might be the quarrel over bonuses between Togo's national football team and the national federation shortly before and during the FIFA World Cup in Germany. Poli/Dietschy (2006: 183) regard football as a "site d'investissement politique privilégié" in countries like Togo and Gabon. For FIFA, Africa and governance questions see Darby (2002).

17 Anouma was made an advisor to the President after he was successful in managing the federation, see Mehler/Njoya 2006, Poli/Dietschy 2006. He was elected into the FIFA executive committee in 2006 and can now be seen as one of the most powerful African football managers. 
résiste, c'est la Côte d'Ivoire debout, c'est la Côte d'Ivoire qui gagne"18. This is without doubt an anti-colonial and anti-rebel statement. Resisting, standing upright and winning not only a game, but the civil war is the message conveyed.

In crisis-ridden Côte d'Ivoire football represented a badly needed feel-good factor over the last twelve months. Soccer is seen by many Ivorians as the only thing that truly unites the people. Star player Didier Drogba (FC Chelsea) was time and again portrayed as a national hero. To be associated with him can bring a lot of political gain to public personalities including politicians. The opposition daily le Patriote writes

"Qu'on appelle cela le nationalisme, le civisme ou le patriotisme, peu importe. Une chose est sûre, les Eléphants donnent du baume au cœur et des raisons d'espérer en la nation ivoirienne de demain. Didier Drogba et ses complices sont aujourd'hui des icônes pour les jeunes." ${ }^{19}$.

The irony of Drogba's rise to a national hero lies in the clear "post-national" nature of his own career - raised in France, never playing for an Ivorian club, being part of the global carrousel of sales and re-sales of talented players etc. And this is of course not a peculiarity of Drogba alone. ${ }^{20}$

The wide variety of reporting Gbagbo's words (allegedly literally) at the occasion of a reception after the qualification of the national team is of great interest. While the quasi-official Fraternité Matin quotes Gbagbo lauding the Elephants "C'est pourquoi, je veux les offrir, ce matin, au peuple de Côte d'Ivoire, à la Nation, en modèle, en exemple", the more partisan Le Temps adds an interesting word "C'est pourquoi, je veux les offrir ce matin, au peuple d'Eburnie, à la Nation, en modèle, en exemple" - 'L'Eburnie' is a synonym for Côte d'Ivoire stressing a more indigenous self-esteem. ${ }^{21}$ The most neutral formulation has been chosen by

18 Notre Voie, May 16, 2006.

19 www.lepatriote.net, June 12, 2006. Sports and role models for youths would obviously be another interesting topic for comparison, but this is beyond the aim of this contribution.

20 A presentation of a first draft of this paper at the 20th international congress of the German Association of African Studies in Frankfurt am Main, July 25, 2006, led to some remarks in this direction. Thanks go to Peter Alegi and Mamadou Diouf for discussing this aspect and reminding it to me.

21 According to University of Nice's review Le français en Afrique $(16 / 17,2002)$ the word is: "apparu vers 1995, écrit, oral, lettrés, souvent en contexte satirique" (www.unice.fr/ILFCNRS/ofcaf/16/E.htm). Gbagbo supporters use the name in a context of national liberation. One open letter to Abidjan.net might show this (title "Gbagbo - le Arafat éburnéen"): "Laurent Gbagbo se hisse au rang de grand libérateur de l'Afrique à l'image d'Arafat en déjouant un complot colonial. La Côte d'Ivoire se libère enfin. Monsieur le président, changez par décret le nom de la colonie "de fait" française en République d'Eburnie. Les éburnéens vous glorifient. Bravo de dire non au nouvel ordre mondial d'après le 11 septembre que les occidentaux veulent nous imposer? Comme s'ils en avaient été autorisé par un droit divin. Merci de résister comme Mugabé et Hugo Chavez. L'Afrique francophone s'émancipe." (www.abidjan.net/lettreouverte/lettre.asp?ID=5037, access: July 17, 2006). 
the sensational, but rather independent paper Soir Info with a simple "Je vais offrir ces jeunes gens à la Côte d'Ivoire en modèle". It is evident that the three papers follow different lines. A second example from the same texts may stress this. While Fraternité Matin cites a passage of Gbagbo's speech with "Parce que la victoire finale est la fin de la guerre (...) [brackets in the original text]. Pour tous les Ivoiriens, c'est cela la victoire finale", Le Temps fills the brackets and writes "parce que la victoire finale, c'est la fin de la guerre tout comme celle de la crise. C'est ça la victoire" (without any 'final' quality), Soir Info goes a step further with a "La victoire ne sera totale [sic !] que lorsque la guerre prendra fin" 22 - Football is what you make of it.

In Ghana, a quite familiar, maybe universal appeal to honour was expressed several times by official authorities. "Defend the honour and the pride of the nation" are in fact words of president Kufuor extended to the "Black Stars" (the name of the national football team) before they left for Germany. After qualification for the World Cup and before the African Cup of Nations he was already quoted

"I salute you for your dedication, devotion and determination to raise our national flag and Ghanaians are looking forward to more days of celebrations in the CAN 2006."

Nothing particular in those words. And maybe that the nice proposal by Ghana's National Sports Council to create the institution of a "Patriotic Month" to sustain the high level of patriotism the country experienced as a result of the "sterling" performance of the Black Stars in the 2006 FIFA World Cup is just worth a footnote..$^{23}$ But Ghana is more specific with regard to a somewhat broader mission. Foreign Minister Nana Akufo-Addo, in a press briefing on 21 June (that is a day before winning the third match of the tournament) said that the Black Stars are "not just representing the nation but Africa". Ghana's officials, the players themselves ${ }^{24}$ and in fact also those reporting about events around the World Cup attribute a role of ambassador of Africa in the world to the team and the whole country. This expresses a sense of pan-africanism deeply felt in Ghana founded back in the years of Nkrumah's reign. In fact, Nkrumah himself is quoted on a West African NGO's website “Sport's role in nation-building is multi-faceted: a victory in a major international sporting event is of national importance." Nkrumah reportedly had a dream of a 'united African country' where sport would play a vital role in forging the youth into one nation. And again, according to Nkrumah, "sporting success gives dignity and pride". In 1960, when the Ghana national

22 Sources: Fraternité Matin, October 11, 2005, Le Temps, October 11, 2005, Soir Info, October 11, 2005.

23 www.accra-mail.com/mailnews.asp?ID=17163, access: July 7, 2006.

24 Ghana captain Stephen Appiah is quoted "People didn't expect us to play like the way we played. I think all Ghanaians are happy, not only for Ghana but for the African continent as well.", www.denverpost.com/rapids/ci_3964818, access: June 22, 2006. 
football team made a tour of Europe, Nkrumah reportedly instructed them to go and correct the Europeans' prejudices about Africa. "He saw sport as the first step towards building a formidable team which could contribute to the emancipation of Africa." 25

This very particular mode of patriotism, also expressed numerous times by Ghana's President Kufuor, can be found in different media reports. One example - a day before the decisive third match against the USA - might be enough to remind the pan-africanist mission “(...) I have no doubt that you are capable and will cross this last group hurdle into the next stage of the competition to make Ghana and Africa proud." 26

Main opposition party NDC could not stay behind and issued a statement shortly before the first match during the tournament. The Ghanaian News Agency is quoting from this document:

"It said, virtually all the members of the present Black Star Squad made the nation proud in the past when they defied all odds to chalk magnificent successes all the way to the Olympic Games."

The direct quote re-taken by GNA reads

"The task ahead does not promise to be but easy, but we believe that with determination, self-belief, discipline and a recollection of glorious peaks attained in our recent past the team can rise to the occasion and make Ghana and Africa proud." ${ }^{27}$

The NDC statement thereby relates patriotism and pan-africanism in a Nkrumaist fashion just like Kufour did.

Maybe it is of interest that President Gbagbo of Côte d'Ivoire tried as well to ride the panafricanist wave by inviting the Presidents of the football associations of all qualified African countries to the World Cup to a ceremony in Abidjan in May 2006 - handing out decorations to all of them and appealing to a pan-african spirit. ${ }^{28}$ In fact the left-leaning past of his FPI

25 www.gppac.net/documents/pbp/8/2_intro.htm, access: June 26, 2006.

26 www.ghanaweb.com/GhanaHomePage/soccer/artikel.php?ID=106210, access: July 18, 2006. This special role is somehow acknowledged as well from all over Africa. See "YYou have done us proud' - ECOWAS to African Teams", www.accra-mail.com/mailnews.asp?ID=17107, access: July 11, 2006.While ECOWAS secretary general Ibn Chambas, a Ghanaian, may be affected by that national fever when he lauds "the talent, exuberance, dynamism and sense of purpose of the emergent African youth and the ability of Africa to compete with the rest of the world on an equal footing" (he cites all participating African nations) this could not have influenced a report from Nigeria. Africa Today quoted the sports editor of another journal, the Punch, "Nigeria are not here but we are journalists first and foremost, and again, we are also Africans and we support the African teams. (...)We feel bad that the Eagles are not here but we are happy that Ghana played so well $(\ldots)^{\prime \prime}, \quad$ www.africatoday.com/cgi-bin/public.cgi?sub=news\&action=one\&cat=123\&id=648, access: July 11, 2006. This is without doubt a feeling shared by many Africans.

27 www.ghanaweb.com/GhanaHomePage/SportsArchive/artikel.php?ID=105670, Soccer News of Sunday, access: June 11, 2006; emphasis added.

28 AFP, May 19, 2006. 
party and the opposition to founding father Félix Houphouët-Boigny who was himself a kind of rival to Nkrumah at his time may explain a similar view on politico-philosophical issues. $^{29}$

Patriotism and self-esteem is another link to be found in Ghanaian media reports or internet forums. E.g.

"The 2006 World Cup is about little Ghana, discovering that we will not settle for the silver that is always offered to us and now competing for the ultimate prize. The Black Stars are shocking all Ghanaians into awareness about their inherent worth. Their story and grit, epitomized by Razak Pimpong limbering on in the wake of an obvious injury and bringing glory to Mother Ghana, is one that all Ghanaians, irrespective of colour, shape or form should tap into. We are beginning to believe! And it can only do wonders for us as a nation!" 30 .

\section{Peace: To Have or to Have Not}

The "Elephants" were time and again used to show that peace is possible in Côte d'Ivoire. By its composition, but as well by clearly expressed wishes for peace the national team made a strong show at home. ${ }^{31}$ One example of the "lessons learnt" might suffice: The government's daily Fraternité Matin published an editorial on June 19, 2006 that will be quoted again: “Petits gestes, grands symboles: Drogba a embrassé ses adversaires. Drogba a serré la main à 'ses assassins'". The strong wording must remind the Ivorian public about the critical political situation and the need for reconciliation.

The current situation of neither war nor peace is sometimes difficult to address directly, the euphemistic term "crisis" is therefore used instead of violent conflict. Opposition newspaper Le Patriote has interviewed one of the heroes of the Elephants, Aruna Dindane, and asked:

"Vos deux dernières victoires ont été suivies de scènes de liesse en Côte d'Ivoire. Vous êtes conscients du rôle que vous avez dans votre pays qui traverse une crise difficile ?" -

“Oui, on le sait. J'ai vu un peu à la télévision les images après la victoire contre le Cameroun. C'est en pensant à tous ces gens qu'on se sent obligé de gagner. Cela nous met une pression positive. Avec cette crise que traverse le pays, c'est vraiment important de faire plaisir à tous ces gens. Quand on gagne, le peuple est content."

29 In an interview published as a book in 1989 Gbagbo explains why he was in favour of a West African Federation of States, at that time a more realistic alternative to the pan-african dream; Gbagbo 1989: 65ff. All FPI programmes reserve some space for the party's programme in the area of sports.

30 Gold Is Better Than Silver - Thoughts on Ghana's World Cup Experience; www.ghanaworldcup.com/stories/gold_better.html, access: June 26, 2006.

31 Le Monde (Paris), June 10, 2006; Spiegel Special, 2/2006 (Hamburg): Planet Fußball. 
The mood was more confrontative when the Elephants had just qualified in October 2005.32 Gbagbo is cited in the FPI-daily Notre Voie with the following statement:

“Un pays qui est en guerre et qui se qualifie pour la coupe du monde, est-ce que vous voyez un peu ce que cela représente comme symbole ? Et puis vous voyez qui marque les buts? Aruna, un enfant qui a été naturalisé. Mais, l'équipe nationale de football, on ne fait pas la différence. On ne parle pas de xénophobie. Chacun au poste où le pays le met joue son role" 33 .

In fact, naturalisation was one of the core topics of political debate in Côte d'Ivoire over the last couple of years. It affects the highly sensitive issue of civil rights of citizens of mostly Burkinabè and Malian origin. The FPI suspects that the issuing of identity cards to hundreds of thousands of foreigners would be a ploy by its adversaries to win postponed elections. The nationality code and the legal process of naturalisation were amended by Parliament in late 2004 as a consequence of the peace accords of Marcoussis and Accra III. Public hearings to identify rightful applicants were held in the preparation of elections (and technically speaking of electoral registers) all over the country in summer 2006 where nationality certificates were handed out, sometimes disturbed by "young patriots" and other groups.

The rebel-sympathising Nord-Sud journal makes something completely different out of Gbagbo's words. Allegedly quoting Gbagbo literally as well we read:

“La jeunesse n'a pas à prendre les armes. C'est la leçon de Arouna: les gens ont dit que nous étions xénophobes! Arouna vient d'ailleurs, il a été naturalisé ivoirien. C'est Arouna qui nous offre la Coupe du monde".

And it is interpreted subsequently:

32 This was shortly after the African Union's Peace and Security Council decided that Laurent Gbagbo would remain as head of state for another year - elections were originally planned for October 2005. RDR newspaper Le Patriote consequently runs a story "L'annonce de la qualification des Eléphants - Bouaké fête sobrement" (Bouaké is the stronghold of the rebellion). The dominant feeling of Bouaké inhabitants is reported as "Nous sommes des Ivoiriens, c'est vrai, la qualification nous fait énormément plaisir, c'est aussi vrai, mais pour l'heure nous sommes préoccupés par autre chose", Le Patriote, October 10, 2005. Quite the opposite feeling was recorded by the more or less sensational newspaper L'inter, October 10, 2005 (Title: “Après la qualification des Eléphants Des soldats au front exultent Cette victoire va accélerer la réunification du pays").

33 Notre Voie, October 10, 2005. Gbagbo's speech (as cited) contains other interesting quotations "Mais ses buts ne sont pas des buts xénophobes. Ce ne sont pas de buts d'exclusion. Ce sont des buts ivoiriens", or "Nous avons reçu des coups de fil de toutes les régions du pays, même de Ferkessedougou" (this is a rebel stronghold close to the border with Burkina Faso). 
"Quand le chef de l'Etat associe le nom d'Arouna à la jeunesse qui prend les armes, son subconscient parle pour lui. Il suffit de gratter la paille des mots pour comprendre qu'il associe les origines lointaines d'Arouna Dindane (burkinabé) à la rébellion." 34 .

The role of a success in sports for the political dilemma of Côte d'Ivoire has been frequently highlighted in the course of the last twelve months. ${ }^{35}$ This is understandable, but doubts are permitted whether football alone will help. Still, some intriguing formulations may be found even in sports coverage. After the third match at the World Cup, this time won by the Elephants, le Patriote, close to the opposition party RDR, clearly uses 'politically coloured words', probably not in an innocent way:

"Il a fallu une rébellion aux Ivoiriens pour se remettre dans le match. Aruna Dindane, très en verve et soutenu par un Kader Kéita en réussite dans les passes et un Zokora Didier, très autoritaire dans la récupération, ont pu ramener, après la pause, la Côte d'Ivoire dans la compétition."

It appears that also the country needs or needed 1. a rebellion (like the one experienced in 2002) and 2. a strong (non-elected?) leader - maybe an allusion to Ouattara.

Unsurprisingly, reports in the Ghanaian press are hardly speaking about peace and football. But a report by independent journal Public Agenda ${ }^{36}$ from the northern city of Tamale suggests that links are made. After describing cheering crowds when Ghana qualified for the 1/16 finals he concludes that there are no parties anymore: "The political party is Ghana" 37 , a bit like the German Kaiser's (the real one) "Ich kenne keine Parteien mehr, ich kenne nur noch Deutsche" ${ }^{\prime 38}$. This topic comes back in an editorial in the Heritage journal, close to opposition party $\mathrm{CPP}^{39}$ :

"For once, as stated by the Black Stars' captain himself, Stephen Appiah, the gallant efforts of the team have united the Ghanaian nation in a way that has never been seen in the history of this country. No talk of NDC or NPP, no talk of Ashantes and Ewes, no

34 Nord-Sud, October 11, 2005. In the same edition another article deplores the absence of opposition politicians at the official reception for the players. Gbgabo would have missed this opportunity for reconciliation.

35 Le Patriote, February 8, 2006 (during the Africa Cup of Nations).

36 Public Agenda is associated with the Integrated Social Development Centre (ISODEC); for the background see www.ghanaweb.com/public_agenda/article.php?ID=4602, access: July 17, 2006.

37 Amos Safo: Black Stars Unite Abudus And Andanis, in: Public Agenda (Accra), June 30, 2006, posted to the web July 3, 2006 (via allAfrica.com), http://allafrica.com/stories/200607030569.html, access: July 18, 2006.

38 Wilhelm II. "Thronrede", August 4, 1914, Reichstag Berlin, after Germany's entry to the first world war.

39 One of the journal's backers is Kwabena Duffuor, presented as a potential candidate in the 2008 presidential elections for $\mathrm{CCP}$, see

http://cppghana.blogspot.com/2005_05_01_cppghana_archive.html (access: July 17, 2006). 
Abudus or Andanis, no Kotoko or Hearts ${ }^{40}$, everybody was united on a common feeling of patriotism and love for the Ghanaian nation." 41

Let me quote again from the first report from Tamale:

"For once the Abudus and the Andanis, who had for decades lived in mutual distrust over chieftaincy disputes came out openly and embraced each other. The feeling of 'we against them' gave way to that of brotherly and sisterly feeling, bonded by the Black Stars' heroic performance at Fifa's western dominated world cup, marred by biased officiating against

African teams. The Black Stars' feat and its unifying force have compelled some peacebuilding experts and development workers in Tamale to suggest that Football should be officially adopted as a conflict resolution mechanism."

The journalist concludes

"The peace overture the Blacks Stars brought should be the beginning of a bigger plan to bring permanent peace. The path to peace should be paved not just with the one-off world cup, but also with long-term efforts of stakeholders." ${ }^{42}$.

\section{Good Governance: Learning from Football or Vice Versa}

The Ivorian government's daily Fraternité Matin and its respected editor-in chief Alfred Dan Moussa - somewhat above the quarrels of political parties - writes an editorial after the first two defeats of the national team at the World Cup, that by celebrating the players criticizes the politicians:

40 Over one hundred people died in a stampede at a football match in Accra in May 2001, in one of Africa's worst sporting disasters, involving the two main club teams of Ghana. After the home team Accra Hearts of Oak scored two late goals to beat Asante Kotoko 2-1, Kotoko fans began destroying plastic seats and the police fired tear gas into the crowd. This caused the stampede. Both clubs have fanatic supporters. Similarly, supporters of the two top Ivorian clubs, ASEC Mimosa and Africa Sports, clashed violently during a local league derby in the same year causing one death. Source: www.crowddynamics.com/Disasters/ghana_2001.htm.

41 Stars Deserve It! The Heritage, posted on July 5, 2006, Editorial, www.theheritagenews.com/article.asp?id=1334, access: July 18, 2006. The more protocol-style entry at the Federation's website is less impressive, see

http://ghanafa.org/gfasite/news/read.php?contentid=2057\&catid=1\&subid=1, access: July 11, 2006. Sheikh Umar Musah, Ashanti, Region Chief Imam, is quoted by the Ghanaian News agency as urging "the government and other political parties to take advantage of the prevailing 'unity of purpose' atmosphere in the country and build upon it in order to sustain the unity of Ghanaians at all times. Use the World Cup competition to promote unity...". In Accra Daily Mail, July 5, 2006, Editorial, www.accra-mail.com/mailnews.asp?id=17179, access: July 18, 2006.

42 Amos Safo: Black Stars Unite Abudus And Andanis, in: Public Agenda (Accra), June 30, 2006, posted to the web July 3, 2006 (via allAfrica.com), http://allafrica.com/stories/200607030569.html, access: July 18, 2006. 
"Le Mondial et, surtout, Drogba et ses coéquipiers font oublier la guerre, les milices, les grèves, les détournements, la fraude, le racket, la corruption, le sida... Drogba et son équipe renvoient dans les tiroirs de l'oubli, ne serait-ce que durant un mois, tous ceux qui, dans la vie estudiantine comme dans la vie active, rament à contre-courant de l'excellence et que l'environnement, par son silence profond, aide à développer pareil schéma. A partir de la mi-juillet, quand les derniers échos du Mondial seront tus, les médiocrités referont forcément surface et tenteront, à leur tour, de faire taire, sans interruption, le nom de Drogba et de tous les Eléphants." ${ }^{43}$.

This paragraph clearly contains a pessimistic tone.

In the already quoted article of Notre Voie other aspects of this topic are reported.

“Quand dans le cadre d'une même manifestation sont célébrés le président Gbagbo, chef de l'Etat, et l'ambassadeur Jacques Anouma, on magnifie sans conteste un tandem qui marche, un tandem sain et efficace." ${ }^{44}$

Ivorians might have been used to the discursive image of "tandem" before. In fact, it is an expression used to describe the dual leadership between Prime Minister Konan Banny, imposed to some degree by the international community, and President Gbagbo. The message therefore might be somehow screwed: since the tandem Anouma-Gbagbo allegedly works the reader might be invited to think that the other tandem - Banny-Gbagbo - is not working. And the fault would necessarily be with Banny. An opposite, positive interpretation would be that tandems are generally the solution for the country's main problems. The message conveyed would be: let us accept tandem solutions for better governance. Difficult to decide what resounds in the ears of Ivorians, but there is more reason to believe it is the first interpretation.

What is certainly more evident from the quotation is that the journalist and probably Gbagbo himself wants to profit from the association with a successful manager. Another quote attributed to the FPI MP already cited might support this statement about a whole strategy:

“'Les populations d'Adzopé, Anyama et Alépé constituées principalement par les Akyé, Agwa et Agni remercient Dieu de leur avoir donné Jacques Anouma, étoile du football, et de l'avoir associé à Laurent Gbagbo, étoile de la politique' a-t-il dit".

And President Gbagbo returns the compliments to Anouma, as reports Notre Voie:

“Pour le chef de l'Etat, la Côte d'Ivoire a eu par le passé de nombreux bons joueurs, mais elle n'avait pourtant rien pu gagner. A l'en croire, il y a deux facteurs qui font que la Côte d'Ivoire gagne: de bons joueurs qui évoluent dans les plus grands clubs du monde et un bon management qu'il faut mettre au crédit de Jacques Anouma. C'est

43 Fraternité Matin, June 19, 2006, Editorial.

44 Notre Voie, May 16, 2006. 
pourquoi le président Gbagbo demande aux Ivoiriens de reconnaître le mérite d'un des leurs si celui-là travaille bien. C'est le cas du président de la FIF."

This was not exactly the terms used by $\mathrm{Gbagbo}^{45}$, but this translates more or less the sense of his intervention.

However, and interestingly, the journalist did not report some other parts of Gbagbo's speech in which he alludes to also discreet and informal ways of helping the prestigious sport: Gbagbo's improvised speech as reported by the Presidential homepage reads:

“j'aide la fédération de football comme j'aide toutes les fédérations ivoiriennes. (...) Il y en a qui dépasse le ministre, ils viennent directement. Mais, C'est le football, c'est le sport, ce sont les sports ivoiriens, on aide, parce que nos sports n'ont pas beaucoup de moyens. Donc, voilà ce que nous faisons." ${ }^{46}$.

This is a direct allusion to some informal ways of funding a sport whose success could be helpful for Gbagbo in return. It looks like defending some bad practices in the name of sports. Interestingly, as already mentioned, the journalist did not report this part of the speech.

Although Ghana fares much better in the eyes of most observers and Ghanaian citizens ${ }^{47}$ than neighbouring Côte d'Ivoire, governance problems remain. And they are recognised as problems in the eyes of Ghanaian media. Posted the day of the third match in the World Cup tournament another article in Ghana Web bluntly states "The story of African soccer is much like the African nations themselves: abundant resources squandered by organizational dysfunction." 48 .

This is of course not the opinion held by the President of the Ghana Football Association (GFA), Kwesi Nyantaki. In his goodwill message he claims that "good management" is behind the success of the Black Stars:

45 Ibid. Most of Gbagbo's speeches can be found at the presidency's homepage, here www.presidence.ci/discours/?current_page=21, access: July 18, 2006. There could be manipulation at this level as well, but to selectively quote is a peculiar technique of newspapers.

46 Ibid.

47 Ghana is one of the very few countries continuously under scrutiny of the Afrobarometer. Survey polls attest that satisfaction with democracy has grown from $54 \%$ in 1999 to $72 \%$ in 2002 (with a slight decline to $70 \%$ in 2005 - while outright dissatisfaction continuously declined from 32 to 25 and finally $15 \%$ ). $77 \%$ of the respondents saw elections as free and fair in 2005 compared to $62 \%$ in 1999, www.afrobarometer.org/papers/AfrobriefNo18.pdf, access: July 18, 2006. Corruption remains an issue. While the President and his environment are well rated this is not the case for judges, border officials and the police. $53 \%$ of the respondents of the $2002 / 3$ survey believe that most/all police officers are involved in corruption, www.afrobarometer.org/papers/AfropaperNo34.pdf, p. 43, access: July 18, 2006.

48 "Ghana Controls Its Own Destiny" (June 22, 2006), www.ghanaweb.com/GhanaHomePage/soccer/artikel.php?ID=106245, access: July 18, 2006. 
"Our achievement was piggy-backed on hard work, team spirit, an unflinching selfbelief and an attitude to die and sacrifice for the nation stridently exhibited by all the major stakeholders in Ghana football. To the hard working players and their management we say a big AYEEKOO. We applaud you for a great job artfully planned and professionally executed." 49

When Ghanaian officials were accused of fraudulently selling tickets in some Western media (quickly denied) other voices were heard, but some remained quite polite. One reads:

"Hello Ghanaweb. Can you please help me send this message to GFA? I am appealing to the members of the Ghana football association to do all it can, within its power, to help Ghanaians get as many tickets as possible to the Ghana-Brazil game. We all want to do our part to help the team progress. It will be a pity to see a stadium full of Brazilian supporters and a few Ghanaian supporters. Please, sell the tickets you have to Ghanaians and Ghanaians only. I don't mind how much you sell it, but please refrain from selling it to foreigners who will support the opposing team." 50

This e-mail gives a clear idea what kind of corrupt practices can still be accepted - and what not.

\section{Conclusions}

Before resuming what we have witnessed a cautionary remark seems appropriate: The comparison of sports coverage between Côte d'Ivoire and Ghana is certainly far from complete by focusing on only three issues and by quoting a small selection of articles and opinions expressed in internet forums. A more systematic procedure of collecting and analysing all articles from relevant electronic sources over a certain time span would have produced maybe more ambiguous results and certainly a majority of articles without political overtones. As a consequence the quotations presented here could only be termed indicative.

But they tell something about "political knowledge", each in its own way. Taken together they might draw a picture of both countries and typical representations of important issues of debate. Roughly we find a Ghana where patriotism is rarely alluded to in day-to-day practice, but when it is - and this is frequently the case when football comes in -, it is quickly merged with pan-africanism. Across the board Ghanaians and their leaders see a special role of Ghana for the entire continent. In Côte d'Ivoire all sides of the political game claim patriotism for themselves and deny it to others. However, the national soccer team, by

49 Goodwill Message by Mr. Kwesi Nyantakyi President of the Ghanaian Football Association, www.ghanaworldcup.com/stories/good_will.html, access: June 26, 2006.

50 Fosu, Charles Kwabena: Open Letter to GFA. Posted to the internet June 26, 2006, www.ghanaweb.com/GhanaHomePage/NewsArchive/artikel.php?ID=106449, access: July 18, 2006. 
its very composition, is a symbol of national unity and somehow untouchable. The Elephants renewed the debate about "Ivorianess" by putting forward a notion of inclusive patriotism. At least, a good part of the news coverage in Ivorian media would support this conclusion.

It is harder to be so assertive with regard to peace. Although once again the implicit and explicit message by the Ivorian team itself just like by the national football federation FIF was in favour of peace, the news coverage and opinions expressed were not always so unambiguous. The rift is deep between the camps. Taking up arms is still somehow justified by some opposition groups - when talking about soccer! And to fight it till the end is an implicit message to be found on the government side while reporting about sports! This juxtaposition tells us that still a long road to peace lies ahead. In Ghana, in comparison, such allusions were simply not found. Ghana is a country largely at peace and sports is sports - at first sight. There were no reports found associating conflict and peace in the Northern part of the country and football directly, but at least some of them alluding to the need of national unity.

This finding is to be qualified for the area of good governance. Ghanaian institutions have their share of corruption and mismanagement. Some allusions to those in the world of soccer were found in media reports. However, a transfer to the general situation of the country is generally avoided. This link could be found more extensively in the case of Côte d'Ivoire. The good example of a rather professional football association is cited in favour of the government (as they work closely together) or as a challenge to all political parties (as this quality is rare in politics). Football is what you make of it.

What becomes evident in both cases, however, is the highly politicised nature of football. All political camps act in accordance with a well-learned lesson: You can not leave the pitch to your enemy. George Orwell's well-known quote that "serious sports (...) is war minus the shooting" may have relevance at least in one of the two cases. ${ }^{51}$

51 George Orwell, The Sporting Spirit, first published in: Tribune (London), November 1945. Thanks to Elisio Macamo for reminding me. 


\section{Bibliography}

Afrobarometer Network (2004): Afrobarometer Round 2: compendium of comparative results from a 15-country survey/Compilers: Michael Bratton etc. Cape Town: Institute for Democracy in South Africa.

Akindès, Francis (2004): The Roots of the Military-Political Crises in Côte d'Ivoire. Uppsala.

Akwetey, Emmanuel O. (1996): Ghana: Violent Ethno-Political Conflicts and the Democratic Challenge, in: Olukoshi, Adebayo; Laakso, Liisa (eds.), Challenges to the Nation-State in Africa, Uppsala: Nordiska Afrikainstitutet, pp. 102-135.

Armstrong, Gary (2004): Life, Death, and the Biscuit: Football and the Embodiment of Society in Liberia, West Africa, in: Amstrong, G.; Giulianotti, R., 1.c., pp. 183-209.

Armstrong, Gary; Giulianotti, Richard (eds.) (2004): Football in Africa: Conflict, Conciliation and Community. Houndsmills: Palgrave MacMillan.

Boer, Wiebe (2004): A Story of Heroes, of Epics: The Rise of Football in Nigeria, in: Amstrong, G.; Giulianotti, R., 1.c., pp. 59-79.

Darby, Paul (2002): Africa, Football and FIFA. Politics, Colonialism and Resistance. London: Frank Cass.

Dozon, Jean-Pierre (2000): La Côte d'Ivoire entre démocratie, nationalisme et ethnonationalisme, in: Politique africaine, 78, pp. 45-62.

Gbagbo, Laurent (1989): Côte d'Ivoire. Histoire d'un Retour. Paris: l'Harmattan.

Glaser, Antoine; Smith, Stephen (2005): Comment la France a perdu l'Afrique. Paris.

Hadjor, Kofi Buenor (2003): Nkrumah and Ghana. Asmara: Africa World Press.

Konaté, Yacouba (2003): Les enfants de la balle. De la FESCI aux mouvements des patriotes, in: Politique Africaine, 89, pp. 49-70.

Le Pape, Marc; Vidal, Claudine (eds.) (2002): Côte d'Ivoire. L'année terrible. Paris: Khartala.

Losch, Bruno (2000): La Côte d'Ivoire en quête d'un nouveau projet national, in: Politique africaine, 78, pp. 5-25.

MacGaffey, Wyatt (2006): Death of a king, death of a kingdom?: Social pluralism and succession to high office in Dagbon, northern Ghana, in: The Journal of Modern African Studies, 44 (1), pp. 79-99.

Mehler, Andreas (2002): Rebellion und Putschversuch in der Côte d'Ivoire, in: SWP aktuell, 39, Berlin.

----- (2004): Côte d'Ivoire: Chirac allein zuhause?, in: Afrika im Blickpunkt, Hamburg: Institut für Afrika-Kunde. 
Mehler, Andreas; Biallas, Axel (2005): Nach elf Monaten südafrikanischer Vermittlung: Keine Wahlen in Côte d'Ivoire - Friedensprozess in der Sackgasse, in: Afrika im Blickpunkt, Hamburg: Institut für Afrika-Kunde.

Mehler Andreas; Tchouamou Njoya, Eric (2006): Fußball in Afrika: Mehr als ein Spiel. GIGA Focus Africa, Nr. 6, 2006, Hamburg: GIGA.

Nkrumah, Kwame (1964): Africa must unite. London: William Heinemann.

----- (1973): Revolutionary Path. London: Panaf Books.

Nugent, Paul (2001): Winners, losers and also rans, in: African Affairs, 100 (400), pp. 405-428.

----- (2005): Les élections ghanéennes de 2004: anatomie d'un système bipartite, in: Politique Africaine, 97, pp. 133-147.

Poli, Raffaele; Dietschy, Paul (2006): Le football africani entre immobilisme et extraversion, in: Politique Africaine, 102, pp. 173-187.

Smith, Stephen (2003): La politique d'engagement de la France à l'épreuve de la Côte d'Ivoire, in: Politique Africaine, 89, pp. 112-126.

Tiémoko, Coulibaly (1995): Démocratie et surenchères identitaires en Côte d'Ivoire, in: Politique Africaine, 58, pp. 144-150.

\section{Internet Sources}

Bertelsmann Transformation Index (BTI), in: www.bertelsmann-transformation-index.de/fileadmin/pdf/BTI_2006_Broschuere_D_gesamt.pdf, access: July 31, 2006.

Convention People's Party (CPP) (2006): CPP Will Unbind Ghana From Its Globalised Dependency, in: www.ghanaweb.com/GhanaHomePage/election2004/artikel.php?ID=105783, access: June 13, 2006.

New Partnership for Africa's Development (NEPAD) (2005): Country Review of the Republic of Ghana, available via African Development Bank: www.afdb.org/pls/portal/docs/PAGE/ADB_ADMIN_PG/DOCUMENTS/NEPAD_IN FORMATION/APRM\%20GHANA\%20REVIEW\%20REPORT\%20JUNE\%202005.PDF, access: July 18, 2006. 


\section{G

\section{Recent issues:}

No 26 Martin Beck: Probleme des Rentierstaats-Ansatzes in vergleichender Perspektive [Problems of the Rentier State Approach in Comparative Perspective]; August 2006

No 25 Dirk Kohnert: Cultures of Innovation of the African Poor. Common Roots, Shared Traits, Joint Prospects? On the Articulation of Multiple Modernities in African Societies and Black Diasporas in Latin America; July 2006

No 24 Jan Peter Wogart: Multiple Interfaces of Big Pharma and the Change of Global Health Governance in the Face of HIV/AIDS; June 2006

No 23 Daniel Flemes: Brazil's Nuclear Policy. From Technological Dependence to Civil Nuclear Power; June 2006

No 22 Leany Barreiro Lemos and Mariana Llanos: The Politics of Senatorial Confirmations: A Comparative Study of Argentina and Brazil; May 2006

No 21 Matthias Basedau and Wolfram Lacher: A Paradox of Plenty? Rent Distribution and Political Stability in Oil States; April 2006

No 20 Esther K. Ishengoma and Robert Kappel: Economic Growth and Poverty: Does Formalisation of Informal Enterprises Matter?; April 2006

No 19 Anika Oettler: Guatemala in the 1980s: A Genocide Turned into Ethnocide?; March 2006

No 18 Heike Holbig: Ideological Reform and Political Legitimacy in China: Challenges in the Post-Jiang Era; March 2006

No 17 Howard Loewen: Towards a Dynamic Model of the Interplay Between International Institutions; February 2006

No 16 Gero Erdmann and Ulf Engel: Neopatrimonialism Revisited - Beyond a Catch-All Concept; February 2006

No 15 Thomas Kern: Modernisierung und Demokratisierung: Das Erklärungspotenzial neuer differenzierungstheoretischer Ansätze am Fallbeispiel Südkoreas [Modernization and Democratization: The Explanatory Potential of New Differentiation Theoretical Approaches on the Case of South Korea]; January 2006

No 14 Karsten Giese: Challenging Party Hegemony: Identity Work in China's Emerging Virreal Places; January 2006

No 13 Daniel Flemes: Creating a Regional Security Community in Southern Latin America: The Institutionalisation of the Regional Defence and Security Policies; December 2005

No 12 Patrick Köllner and Matthias Basedau: Factionalism in Political Parties: An Analytical Framework for Comparative Studies; December 2005

All GIGA Working Papers are available free of charge at www.giga-hamburg.de/workingpapers. For any requests please contact: workingpapers@giga-hamburg.de.

Editor of the Working Paper Series: Bert Hoffmann. 